\title{
Red swamp crayfish: biology, ecology and invasion - an overview
}

Tainã Gonçalves Loureiro*, Pedro Manuel Silva Gentil Anastácio, Paula Beatriz Araujo, Catherine Souty-Grosset and Mauricio Pereira Almerão

(TGL, PBA, MPA) Departamento de Zoologia, Universidade Federal do Rio Grande do Sul. Av. Bento Gonçalves, 9500, Bloco IV, prédio 43435. 91501-970 Porto Alegre, Brasil. E-mail: (TGL) loureiro.tg@gmail.com, *Corresponding author

(PMSGA) Departamento de Paisagem, Ambiente e Ordenamento, Universidade de Évora, Rua Romão Ramalho, no 59, 7000-671, Évora, Portugal.

(CSG) Laboratoire Ecologie \& Biologie des Interactions, Université de Poitiers, rue Albert Turpin TSA 51106 F-86073, Poitiers, France.

ABSTRACT - Alien species have been transported and traded by humans for many centuries. However, with the era of globalization, biological invasions have reached notable magnitudes. Currently, introduction of alien species is one of the major threats to biodiversity and ecosystem functioning. The North American crayfish Procambarus clarkii is one of the most widely introduced freshwater species in the world, especially due to its high economic importance. It is responsible for great modifications in invaded environments causing irreparable ecological and economic damages. Its impressive ability to successfully colonize a wide range of environments is a consequence of its behavioural and biological characteristics that can adapt to features of the invaded location, conferring to this species a notable ecological plasticity. This review summarizes the available information regarding P. clarkii's biology and invasive dynamics around the world in order to contribute to the understanding of the threats posed by its establishment, as well as to support management and impact mitigation efforts.

Key words: Alien biology, Exotic crayfish, Red swamp crayfish, Invasive features, Impact, Invasion management

\section{INTRODUCTION}

Human activities such as agriculture, aquaculture, recreation and transportation promote the spread of species across their natural dispersal barriers, a process which has been accelerated due to globalization. Species translocation may be intentional or accidental although most organisms die during the transport or soon after their release. Species that became invasive are those that persist, become established and cause negative effects on human health, economy, native biodiversity and ecosystem function (Kolar and Lodge, 2001).

Indeed, alien species introduction is one of the major threats to biodiversity and ecosystem functioning (Carlton, 1996; Lodge et al., 2000). Some of the best known invasive freshwater alien species are the zebra mussel, Dreissena polymorpha (Pallas, 1771), the Asian clam, Corbicula fluminea
(Müller, 1774), the Nile perch Lates niloticus (Linnaeus, 1758) and the red swamp crayfish, Procambarus clarkii all of which have greatly affected rivers and lakes worldwide (Nalepa and Schloesser, 1993; D’Itri, 1997).

Procambarus clarkii, also known as red swamp crayfish or Louisiana crawfish, is native to northeastern Mexico and the southern USA; it has been introduced in all continents except Antarctica and Oceania, being now considered the most cosmopolitan freshwater crayfish species in the world (Hobbs, 1988; GutiérrezYurrita et al., 1999; Lindqvist and Huner, 1999; Gherardi, 2006; Chucholl, 2011). In a general way, this species shows good tolerance to a wide range of environmental conditions, elevated adaptive capacity, high growth rate and flexible feeding strategy (Hobbs et al., 1989; Gutiérrez-Yurrita et al., 1999; Alcorlo et al., 
2004; Souty-Grosset et al., 2006; Gherardi, 2007), features that favour its establishment in new available habitats.

One of the biggest challenges to understand and predict biological invasions lies in understanding which biological and ecological characteristics might favour the colonization and establishment of exotic species in new areas as well as postestablishment patterns of spread, and how invasive species can outcompete native species. Thus, the present review aims to summarize and update existing information about the ecology, biology and invasive dynamics of $P$. clarkii around the world. Understanding of the invasion process in different countries and habitats as well as comprehending the characteristics of the species that might favour its successful invasions can help managers to recognize the potential threats that this species poses to newly invaded ecosystems and to support management and impact mitigation efforts.

This paper is divided into eleven sections that cover various aspects of $P$. clarkii's systematics, life history, physiology, and ecology, as well as impacts observed in invaded areas. The review encompasses the traditional peer-reviewed literature, but also includes information available on reports and on the World Wide Web.

\section{MORPHOLOGICAL ASPECTS}

Procambarus clarkii's body, as a typical decapod crustacean, is divided into cephalothorax and abdomen, both parts having appendages following the decapod pattern (Hobbs, 1974). The abdominal appendages called pleopods are not always present in decapod males, but in this species, they are present in both males and females (Hobbs, 1974). The thoracic appendages (pereiopods) are five in number, as usual, but the first 3 pairs are chelate, which is a characteristic of the infraorder Astacidea (Taylor, 2002; Crandall and Buhay, 2008; Gherardi et al., 2010). The carapace color is dark red, orange or reddish brown, although blue, yellow, white and black varieties are known (Gherardi, 2011); chelae are typically red on both surfaces. Juveniles are usually light green with a narrow dark band on either side of the abdomen and a broader lighter band along the dorsal surface. Adult specimens can measure up to 15 centimeters of total length, although most individuals are up to 12 centimeters (Henttonen and Huner, 1999).
This species presents external sexual dimorphism and sex can be distinguished by the position of the genital pores. The genital openings are located on the coxopodite of the third pair of pereiopods in females and on the fifth pair of pereiopods in males (Holdich and Lowery, 1988). Moreover, males have a copulatory organ formed by a modification of the first and second pair of pleopods (Fig. 1A) whereas in females the first pair of abdominal appendages is vestigial and the second has no modification (Fig. 1C) (Sukô, 1953; Huner, 1981).

Likewise most crayfish species, $P$. clarkii has sexual reproduction. Sexual maturity is reached in approximately three months and, depending on climate, it may produce two or three generations per year (Dörr et al., 2006). In adult males, two different morphotypes that alternate between each other can be observed: the reproductive form or type I male, with hooks on the ischia of the 3rd and 4th pereiopods and more calcified copulatory organs (Fig. $1 \mathrm{~A})$, and the non-reproductive form or type II male, in which hooks are lacking (Fig. 1B) (Taketomi et al., 1990; Henttonen and Huner, 1999). This morphotype alternation in males is a characteristic of the family Cambaridae (Hobbs and Jass, 1989). An adult male might remain as type I for up to 9 months in a year. Procambarus clarkii females, on the other hand, have no morphological alteration during reproductive phase and the only different characteristic is an increase in its receptivity to males, which might happen more than once a year depending on environmental characteristics (Sukô, 1953).

\section{REPRODUCTION}

The knowledge of the reproductive strategy of invasive species is central to the understanding of its invasion ecology as it determines the potential for population increase and range expansion. In Procambarus clarkii, mating period, as well as recruitment and sexual maturation, vary according to hydrographic period and environmental conditions (Sommer, 1984; Alcorlo et al., 2008) and therefore, due to the combined effects of these factors, reproduction may change after the species is introduced into different regions. 


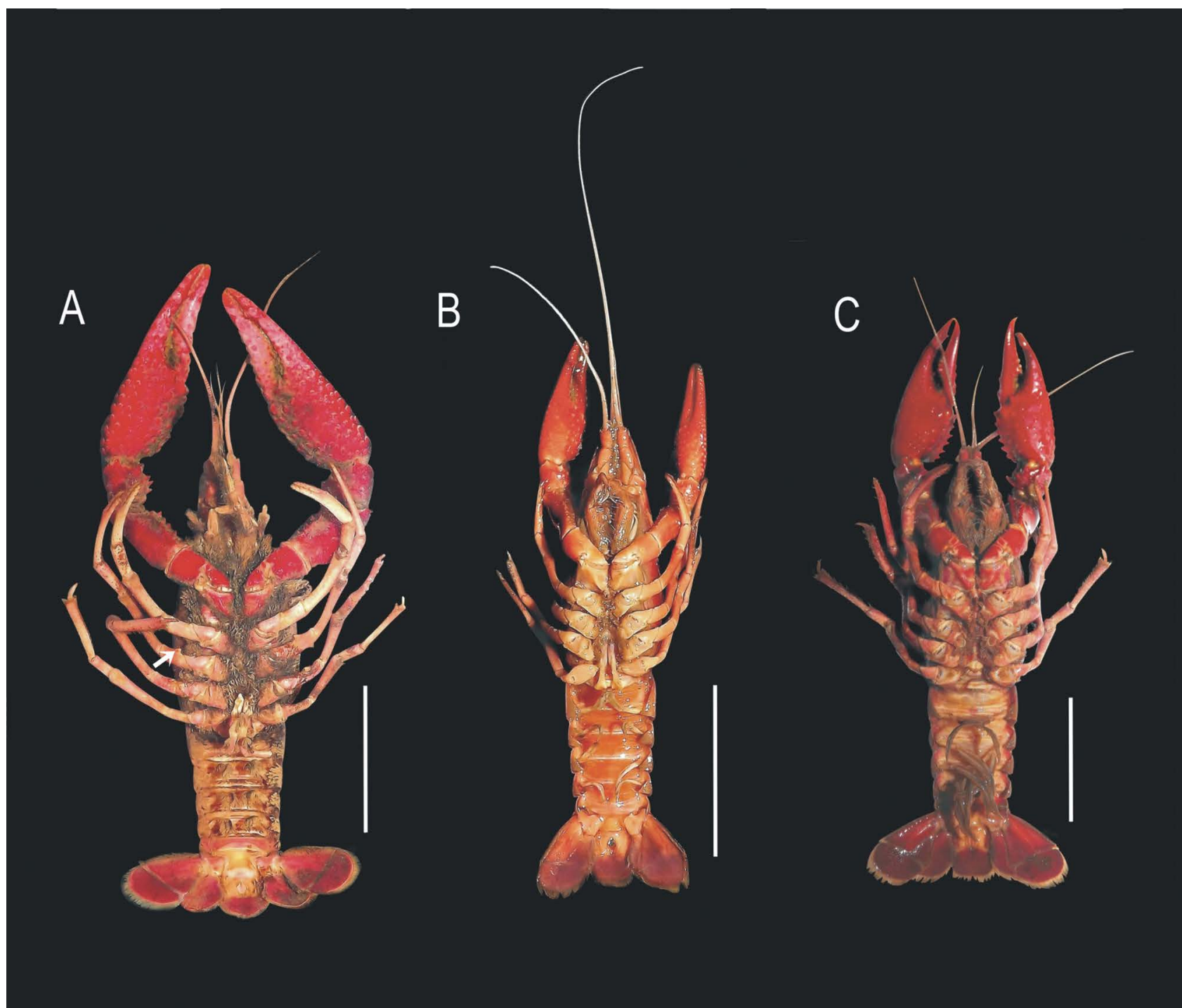

Figure 1. Ventral view of Procambarus clarkii individuals. A: Morphotype I male (reproductive form) showing the more calcified copulatory organ and the copulatory hooks on the $3^{\text {rd }}$ and $4^{\text {th }}$ pereiopods' ischia. B: Morphotype II male (non-reproductive form) without the copulatory hooks and softener copulatory organ. C: Female showing the first pair of abdominal appendages which is vestigial and the annulus ventralis. Scale bars $=2 \mathrm{~cm}$.

Reproduction is regulated by pheromones perceived by receptors located on the antennae which are responsible for interspecific and intraspecific recognition and behavioural modulation (Ameyaw-Akumfi and Hazlet, 1975). After sex recognition, male courts female through a specific sequence of movements followed by copulation, when the male turns the female with her dorsal surface against the substrate, holding her chelipeds and both ventral regions remain in contact. Thereafter, male deposits the spermatophore in the annulus ventralis (not in the genital pore) (Fig. 1C), which is the female's sexual receptacle, located between the bases of the posterior walking legs (Ameyaw-Akumfi, 1981; Gherardi et al., 2010).
Days, weeks or months after mating, depending on environmental conditions, the female safeguards herself in a burrow and starts oviposition; this process may occur in open water but this is very uncommon (Holdich and Lowery, 1988). The number of eggs per brood may reach up to 700 (Penn, 1943; Noblitt et al., 1995) although it depends on female size and is also related to water temperature, population density and the length of the hydroperiod (Alcorlo et al., 2008). The embryonic development time depends on atmospheric temperature and may be inhibited under $10{ }^{\circ} \mathrm{C}$ (Sukô, 1953). After hatching, juveniles are kept under the female's abdomen for three weeks (Holdich and Lowery, 1988). 


\section{TROPHIC ECOLOGY}

Procambarus clarkii is a generalist omnivore species whose opportunistic diet favours its own successful establishment in different types of water bodies (Gutiérrez-Yurrita et al., 1999). Despite the fact that its diet in natural habitats is not widely studied, much information has been collected in its invasive range (D'Abramo and Robinson, 1989; Feminella and Resh, 1989; Ilhéu and Bernardo, 1993; 1995; GutiérrezYurrita et al., 1998; Alcorlo et al., 2004). They are reported to feed on plant and animal detritus, macrophytes and live animals such as molluscs, insects, annelids, nematodes, platyhelminthes, tadpoles and fingerlings (Fig. 2) (Huner and Barr, 1991; Ilhéu and Bernardo, 1993; 1995; Gutiérrez-Yurrita et al., 1998; 1999; Parkyn et al., 2001; Correia, 2002; Buck et al., 2003; Cruz and Rebelo, 2005).

Regarding $P$. clarkii's predators, the most widely cited in literature are fishes, birds and mammals like otters and capybaras (Delibes and Adrián, 1987; Holdich and Lowery, 1988); juveniles can also be eaten by odonate nymphs, coleopteran larvae and aquatic hemipterans (Fig. 2) (Gydemo et al., 1990).
Invasive species might bring exotic diseases that can reach much higher severity than in its native distribution area (Fig. 2). By far, the most known and studied pathogen of $P$. clarkii is the the parasitic Oomycete Aphanomyces astaci, the causative agent of crayfish plague, which is lethal to many species of crayfish (Alderman and Polglase, 1988; Holdich et al., 2009). This pathogen initially infects the exocuticle and after the endocuticle; in more susceptible species or individuals, it penetrates the basal lamina, underneath the epidermis cell layer and spreads throughout the body, invading connective tissue and blood vessels (Cerenius et al., 1988). Aphanomyces astaci does not produce sexual structures, with transmission occurring via zoospores released from infected animals and it is able to survive for several days in water and several weeks in mud (Alderman and Polglase, 1988; Diéguez-Uribeondo et al., 1995; Edgerton et al., 2002). Besides $A$. astaci, another parasitic fungus that can infests $P$. clarkii carapace and constitute a threat to other crustaceans is Saprolegnia parasitica (Diéguez-Uribeondo et al., 1994).

The great threat posed by the introduction of $A$. astaci, was the trigger to initiate studies on freshwater crayfish pathology in the mid-1900s and this organism has become one of the most

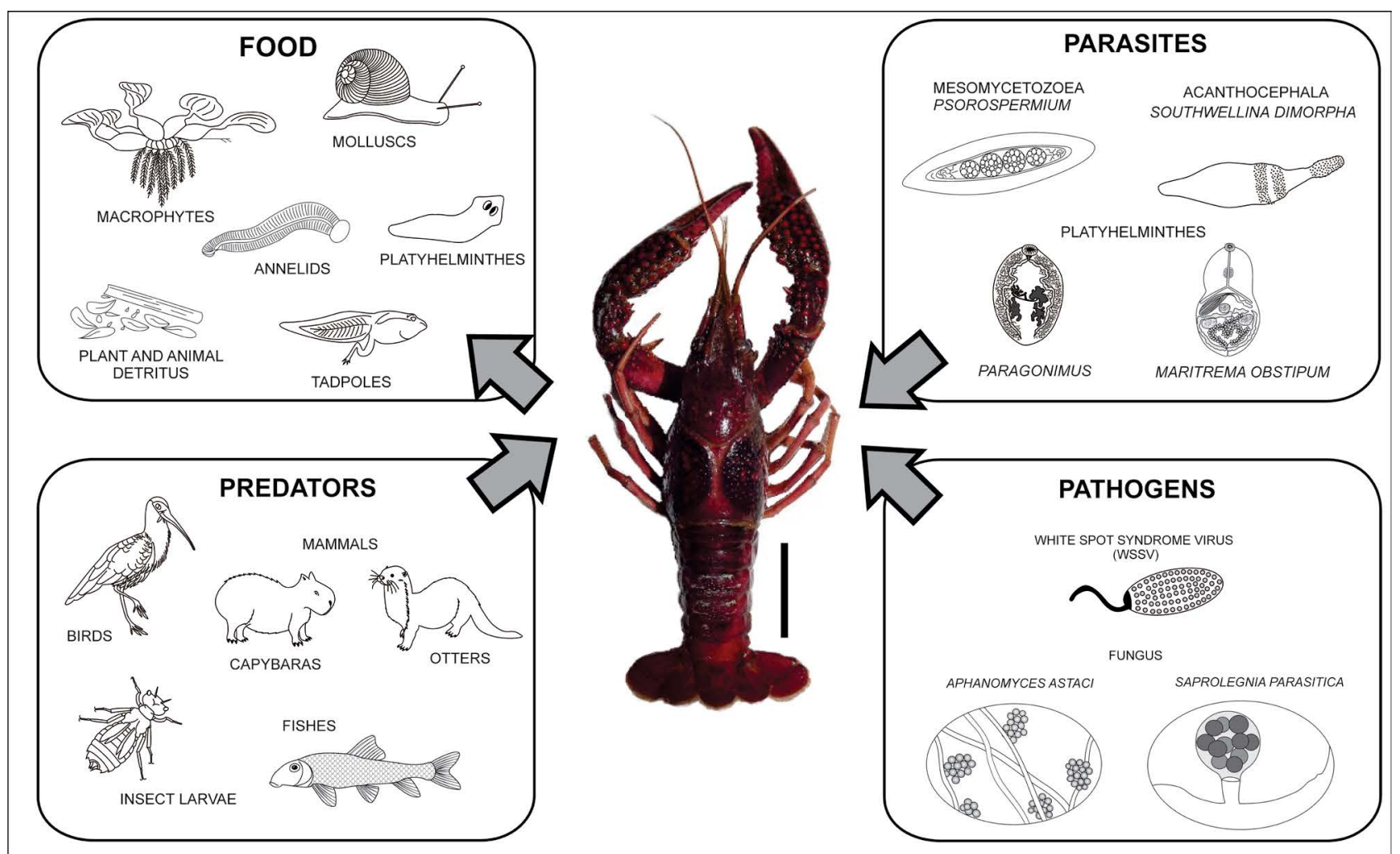

Figure 2. Trophic ecology and biotic relationships of Procambarus clarkii regarding food items, predators, pathogens and parasites. 
intensively studied of all invertebrate infectious diseases (Alderman and Polglase 1988). However, P. clarkii may host many other parasites, pathogens and symbionts that are not as much studied as $A$. astaci, although some of them may affect human health.

Among viruses, the White Spot Syndrome Virus (WSSV) is perhaps the most devastating of all crustacean viruses. WSSV has a very wide host range, including $P$. clarkii (Chang et al., 1998; Baumgartner et al., 2009). Bacterial infections are also very common and can be developed by a variety of Gram positive and Gram negative forms that can inhabit their external exoskeleton, gut and frequently the haemolymph (Thune, 1994). One of the most studied bacteria that affects $P$. clarkii is Vibrio mimicus (Thune, 1991) and it is recognized as a cause of gastroenteritis in humans when feeding on contaminated raw crayfish (Mac Eachern, 2010).

Regarding Platyhelminthes, digeneans are the most common parasites of $P$. clarkii. Within Paragonimidae, species from Paragonimus, highly evolved parasites with a complex life cycle that involves at least three different hosts, i.e., snails, crustaceans, and mammals, are known to use crayfish species, including $P$. clarkii, as intermediate hosts (Sogandares-Bernal, 1965); the adults of Paragonimus reside and mate in the lungs of a variety of mammalian hosts, wild and domestic animals, as well as humans, causing a disease named paragonimiasis (Lane et al., 2009; Procop, 2009).

Some digeneans also may use $P$. clarkii as intermediate host, for example: some species of Microphallus (Microphallidae), whose adults parasitize bird and fish species, being larvae cercariae maybe found in the hepatopancreas of P.clarkii (Overstreet et al., 1992); Maritrema obstipum (Van Cleave and Mueller, 1932) (Microphallidae), whose definitive host are birds and mammals and intermediate host maybe freshwater crustaceans and snails, being larvae cercariae found in the gills and hepatopancreas of P. clarkii (Etges, 1953; Longshaw, 2011); Sogandaritrema progeneticum (Sogandares-Bernal, 1962) (Microphallidae) that parasitizes some crayfishes, including $P$. clarkii (Sogandares-Bernal, 1965; Lotz and Corkum, 1983); Gorgodera amplicava (Looss, 1899) (Gorgoderidae), whose definitive host are some anuran species, may use freshwater bivalves from de family Sphaeriidae and crustaceans as intermediate host. The immature form of $G$. amplicava can be found in the stomach of $P$. clarkii (Longshaw, 2011). Another example is Macroderoides typicus (Winfield, 1929) (Macroderoididae) that uses the freshwater fish bowfin, Amia calva Linnaeus, 1766, as definitive hosts and freshwater gastropods and crayfishes as intermediate hosts. In $P$. clarkii, cysts have been observed in the cephalothorax and antennae (Longshaw, 2011).

Acanthocephalans are obligate parasites that require usually two hosts, an invertebrate and a vertebrate. Typically, the invertebrate host is an insect or a crustacean and the vertebrate hosts can include mammals, birds and fish. These helminths are not considered significant pathogens of freshwater crayfish. However, when there is a high prevalence of infection, crayfishes might become stressed and more susceptible to other diseases (Amin, 1998). Southwellina dimorpha (Schmidt, 1973) (Polymorphidae) is the most studied acanthocephalan observed in P. clarkii and its cysts are in the anterior portion of the crayfish abdomen, usually attached along the intestine (Lantz, 1974; Alderman and Polglase, 1988).

Procambarus clarkii is also vulnerable to microsporidians, intracellular parasites belonging to the Phylum Microspora (Alderman and Polglase 1988). One example is Thelohania contejeani (Henneg, 1892), that has caused mass mortalities of crayfish in Europe (Alderman and Polglase, 1988; Dunn et al., 2009; Edgerton et al., 2002). Another known disease is psorospermiasis, caused by Psorospermium (Mesomycetozoea) that colonizes gills, hepatopancreas, antennal gland, connective and neural tissues, ovary membranes and cardiac and skeletal muscle (Hennton et al. 1994; Ragan et al., 1996; Longshaw, 2011).

Additionally, a range of ectocommensals or ectosymbionts from a number of different Phyla can infest the crayfish exoskeleton, including gills. Most of them are temnocephalans (Platyhelminthes, Temnocephalida) that usually are not pathogenic to crayfish, however, they may impair proper gill functioning if present in such high numbers as to impede water flow in the gill cavity (Edgerton et al., 2002). No temnocephalans were reported on $P$. clarkii but considering their wide range of occurrence among crayfishes (Edgerton et al., 2002; Longshaw, 2011), it is 
believed that the Red Swamp Crayfish might also be infested by them. Branchiobdellidans (Annelida, Clitellata) may also be observed on crayfishes, including $P$. clarkii, but infestations usually take place only when individuals are already ill; infested healthy animals are rarely found (Gelder et al., 1999). Temnocephalids are predominantly found in the southern hemisphere and no branchobdellid species occur naturally in the southern hemisphere (Holt, 1975) although both groups have been found outside their native range, as well as many other crayfish diseases, due to anthropogenic movements of the crayfish host (Gelder, 1999; Volonterio, 2009).

\section{BeHAVIOUR}

Different behavioural characteristics may contribute to the invasive potential of species; aggressive behaviour, for exemple, may influence competitive displacement of native species (Dick et al., 1995; Gamradt et al., 1997; Usio et al., 2000), locomotion and dispersal hability can influence rates of spread and spatial patterns of invasion (Johnson and Carlton, 1996; Lewis, 1998), burrowing behaviour might help coping with environmental stress (Gherardi, 2001) and parental care can improve reproductive fitness by increasing brood survival (Marchetti et al., 2004).

Procambarus clarkii is a social animal with formation of social dominance hierarchies in adults and juveniles (Figler et al., 1995; Issa et al., 1999). Little is known about how the hierarchical relationship forms over time and is subsequently maintained, despite some evidences shown by Figler et al. (1995) where dominance seems to be size-based. High levels of aggressiveness, experience of winning and attacking or approaching first also may contribute to the formation and maintenance of a dominant hierarchy (Bovbjerg, 1956; Lowe, 1956; Copp, 1986; Issa et al., 1999).

This species is defined as nocturnal (Gherardi, 2001) although some individuals were observed performing long displacements both by day and by night (Gherardi and Barbaresi, 2000; Barbaresi et al., 2004). Regarding its locomotion, home-range faithfulness and dispersal abilities, some findings have been controversial, which might indicate that behaviour varies according to environmental characteristics. According to Gherardi and Barbaresi (2000), P. clarkii specimens are capable of major usage of space,

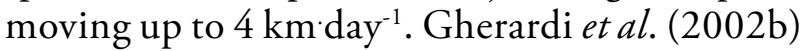
found that locomotory speed is significantly correlated with crayfish size and the extent of locomotion is variable, ranging from 1 to 11 $\mathrm{m} \cdot \mathrm{day}^{-1}$; in this study, neither speed nor distance walked were related to gender. Barbaresi et al. (2004), on the other side, showed that both sexes disperse although males and females use space differently, females being more nomadic than males.

The movement pattern seems to be complex, with one or more short peaks of intense locomotion ("wandering" phases) alternated with periods of scarce mobility, with slow speeds or no movement ("stationary" phases) (Gherardi and Barbaresi, 2000; Gherardi et al., 2000; Gherardi et al., 2002a; Barbaresi et al., 2004; Aquiloni et al., 2005).

Like many crayfish species, $P$. clarkii is an efficient digger wich uses a combination of tactile and visual information, together with environmental use of cues (i.e. humidity cues) to orientate its burrowing behaviour; burrows are used as refuge to avoid predation, dehydration and environmental stress as well as to nest (Huner and Barr, 1991; Barbaresi and Gherardi, 2006). However, despite the great importance of these shelters, individuals seem not to return to previously occupied burrows at the end of their foraging excursions despite the time and energy expended to excavate them (Barbaresi and Gherardi, 2006).

This species, like most freshwater crayfishes, shows relatively complex parental care (Figler et al., 1995; 1997; Vogt and Tolley, 2004). Mothers often remain in their burrow for many weeks as they execute few cleaning and feeding acts; hatchlings and young remain attached to mother's abdomen for 3 to 4 months (Huner and Barr, 1991; Huner, 1994). This behaviour, despite being costly, increases reproductive fitness by augmenting brood survivorship and therefore improving the colonization capability of the species.

\section{GeNETICS}

Genetic analyses of Procambarus clarkii populations are being carried out around the world, using different molecular markers 
Table 1. Studies regarding Procambarus clarkii genetics evidencing the locality investigated, number of populations, whereas this populations are native or invasive, genetic marker used and authors.

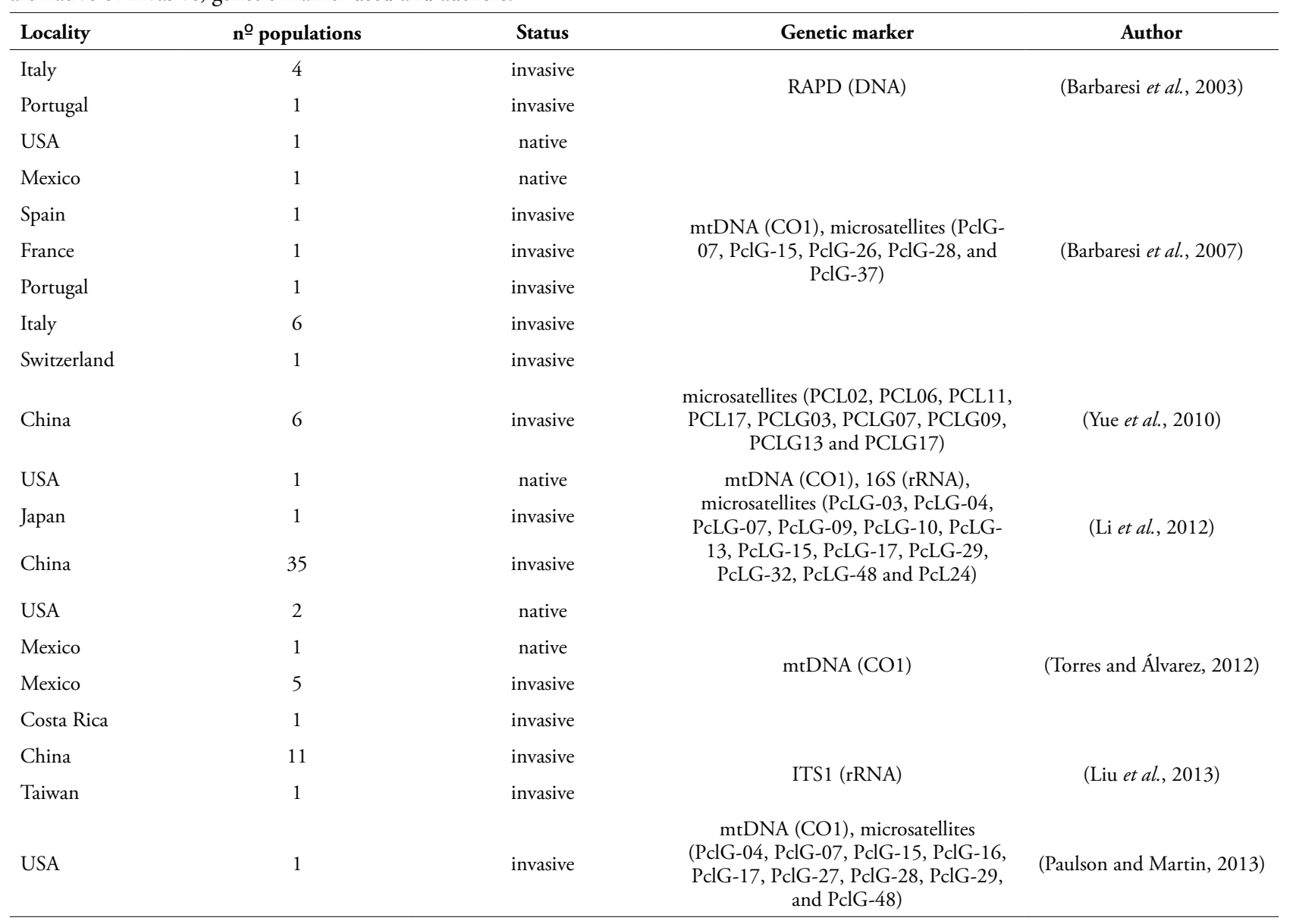

(Barbaresi et al., 2007; Yue et al., 2010; Li et al., 2012; Paulson and Martin, 2013) (Table 1). Genetic information can give helpful insights about connection between populations, and might help to infer the invasion history of exotic populations by identifying the location of origin, colonization events and dispersal routes and thus contribute to the understanding of invasion dynamics and to direct management efforts (Wilson et al., 1999; Kreiser et al., 2000; Lee, 2002; Reynolds and Souty-Grosset, 2012; Paulson and Martin, 2013).

In Europe, the genetic variability of $P$. clarkii invasive populations was first studied by Barbaresi et al. (2003); five populations were analyzed and showed high genetic variation within and among populations. After that, Barbaresi et al. (2007) investigated 12 populations from France, Italy, Mexico, Portugal, Spain, Switzerland and USA; their results revealed a pronounced level of genetic variation in this species that could be the result of multiple introduction events with individuals from different sources and/or a single introduction of a large number of individuals from a genetically diverse source population. These authors also found a high inter-population differentiation, indicating an absence of gene flow among studied populations.

In China, Yue et al. (2010) first studied 6 populations from East China and found evidences of a recent bottleneck and significant heterozygote deficit in all of them, suggesting founder effects and non-random mating; all populations also presented high genetic differentiation between each other. Later, $\mathrm{Li}$ et al. (2012) used genetic information of 35 invasive populations from central and east China to investigate initial entry point(s), dispersal patterns, genetic diversity and genetic structure. The authors confirmed that the city of Nanjing was the first introduction point in China and found a relatively high genetic diversity in Chinese populations which they attributed as a result of adaptive variation or perhaps signaling human-mediated dispersion. More recently, Liu et al. (2013) analyzed 
the population genetic structure among 11 populations from east continental China and one population from Taiwan using different genetic markers. They found an intrapopulation genetic variation of $95.26 \%$, much higher than interpopulation variation (4.74\%) and also observed that the genetic differentiation between Taiwan and continental China populations was moderate, although Chinese populations (Taiwan and continental combined) were highly differentiated from studied North American populations.

In the Ash Meadows, Nevada (USA), investigations regarding the genetic diversity and gene flow between $P$. clarkii populations revealed the colonization process in the area. It was shown that drainages were utilized to move from central to peripheral springs and isolated springs were colonized by few individuals with rare subsequent emigration (Paulson and Martin, 2013).

Torres and Álvarez (2012) investigated the genetic variation among nine populations of the red swamp crayfish, being three populations from its native range (Illinois and Louisiana, United States and northern Coahuila, Mexico) and six from invaded areas (central Coahuila, southern Nuevo León, Durango, Chihuahua and Chiapas, Mexico, and Cartago, Costa Rica); these authors ascertained that populations from the native range remain very similar to each other and that some introduced populations can be directly associated to some of the native populations. Additionally, they found low genetic variation in both native and introduced populations; these results are divergent from almost all studied invasive populations of $P$. clarkii.

The high level of genetic diversity found by different researchers in distinct invasive populations around the world indicates that the high genetic variability of $P$. clarkii might facilitate its success of establishment and adaptation to new environments (Barbaresi et al., 2007). On the other hand, the studies that found low genetic diversity (Torres and Álvarez, 2012) argue that despite this fact, populations are still successful in establish and flourish due to a phenomenon named "general-purpose genotype" proposed by Baker (1965), in which different phenotypes would be produce through plasticity and thus, the population would be able to cope with different environmental conditions.
High genetic diversity in invasive populations is usually related to multiple introductions or the existence of gene flow among established populations while low genetic diversity is associated with isolated introductions, founder effect and genetic bottlenecks. Both genetic scenarios were observed in invasive populations of $P$. clarkii and it seems that this species may cope with both situations by different strategies and succeed.

\section{CAUSES OF INTRODUCTION}

Shipping and aquacultural activities are the main agents of introduction of invasive alien crustaceans around the world (Hänfling et al., 2011). Regarding alien freshwater crayfishes, shipping and ballast water are not important pathways but aquaculture and activities associated with the aquarium and bait industry are (Cohen and Carlton, 1995; Ruiz et al., 1997). Indeed, the aquaculture of Procambarus clarkii is the most important vector of introduction, this species being one of the most important freshwater decapods farmed for consumption (Huner, 1988; Hobbs and Lodge, 2010). Furthermore, this species has also been introduced as food for fishes and for other edible species like bullfrogs (Gherardi et al., 2011; Lodge et al., 2012).

In Africa, $P$. clarkii has also been introduced as a biological control agent to reduce snail populations, which are intermediate hosts of schistosomiasis (Bilharzia) (Lodge et al., 2005). Besides, escapes from garden ponds and the pet trade are also important introduction pathways (Dehus et al., 1999; Soes and Van Eekelen, 2006; Dümpelmann et al., 2009). Furthermore, especially in Europe, the red swamp crayfish has also been introduced to replace indigenous species, like Austropotamobius pallipes Lereboullet, 1858 for example, which was nearly extinct (Anastácio and Marques, 1995; Holdich, 1999).

\section{INVASION RANGE AND HISTORY}

Despite being native to the central southern United States and northeastern Mexico (Fig. 3), Procambarus clarkii has been cultured extensively through the USA and was introduced by humans into different parts of the northern region, currently being found in Arizona, California, Georgia, Hawaii, Idaho, Indiana, Maryland, Nevada, New Mexico, New York, North Carolina, Ohio, 


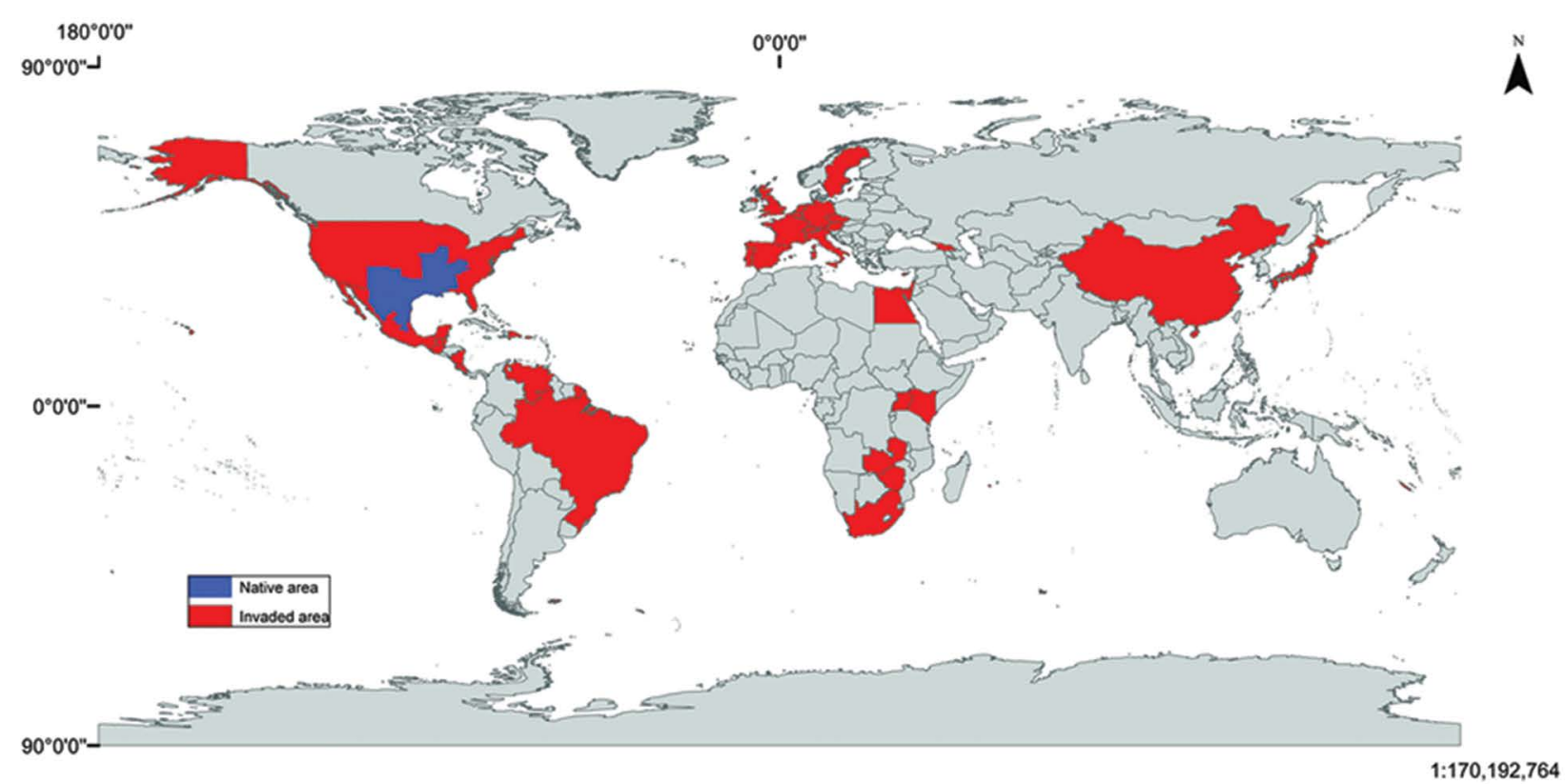

Figure 3. Procambarus clarkii native and invasive distribution in the world.

Oklahoma, Oregon, South Carolina and Utah (Clark and Wroten, 1978; Huner, 1986; Johnson, 1986; Ruiz et al., 1997). In northwestern Mexico, it has been successfully introduced in the states of Baja California and Sonora (Clark and Ralston, 1976; Campos and Rodríguez-Almaraz, 1992).

In Europe, $P$. clarkii was first introduced into the Iberian Peninsula, legally imported from Louisiana for commercial purposes in 1973, at two aquaculture installations in Seville and Badajoz (HabsburgoLorena, 1979). The commercial success led to illegal introductions throughout Portugal, Spain, France and Italy. Thereafter, it dispersed rapidly throughout the Mediterranean region and central Europe, either actively in rivers or passively by human translocations (Anastácio and Marques, 1995; Barbaresi and Gherardi, 2000). Today, the red swamp crayfish is widespread and abundant in Europe, including central and northern European countries, where climatic features were initially considered a potential barrier to its spread (Huner, 2002; Souty-Grosset et al., 2006; Ilhéu et al., 2007; Holdich et al., 2009). In fact, as observed by Chucholl (2011), populations at higher latitudes tend to be sparse and isolated from each other, while at lower latititudes populations are dense and widespread.

In Asia, this crayfish species is widely established in China and Japan. It was initially introduced to Japan in 1927 from New Orleans, USA, as food for bullfrog aquaculture and the pet trade, and now it can be found in the whole country, including Okinawa Islands (Mito and Uesugi, 2004; Kawai and Kobayashi, 2005). From Japan, P. clarkii was introduced to Nanjing, China in 1929 (Yan et al., 2001; Li et al., 2007) and has rapidly spread to most provinces of China, having established dense populations (Li et al., 2005). Furthermore, a reproducing population of $P$. clarkii was also found in Israel by Wizen et al. (2008), but just this first record exists for this country so far.

The red swamp crayfish is also established in Africa, with records from Egypt, Kenya, South Africa, Sudan, Uganda, Zambia and Zimbabwe (Huner, 1988; Hobbs et al., 1989; Arrignon et al., 1990; Mikkola, 1996; Holdich, 1999; Smart et al., 2002; El Zein, 2005; Foster and Harper, 2007). It was originally introduced to Kenya in 1966, from Uganda; after that, active dispersal ability and human mediated translocation resulted in its range expansion through the country (Oluoch, 1990). In Egypt, the first established population was found in the early 1980s, probably derived from a commercial aquaculture facility in Giza (El Zein, 2005; Fishar, 2006) and within the last few years, it has successfully established in various sites of the river Nile and its branches (Fishar, 2006). Regarding P. clarkii invasion in South Africa, Sudan, Uganda, Zambia and Zimbabwe, no historical information about introduction is available, just present occurrence data of established populations. 
Some Central and South American countries were colonized as well, but no information about introduction pathways and dates of establishment are available for most of them. In Costa Rica, invasive populations are known in the provinces of Cartago, Heredia, Alajuela, Guanacaste and Limón (Peña, 1994). Procambarus clarkii occurrence is also registered for Belize, Dominican Republic, Guatemala, Nicaragua, Puerto Rico and Venezuela (Huner and Avault, 1979; Huner, 1986; Hobbs et al., 1989; Williams et al., 2001). In Brazil, P. clarkii has 17 established populations, all of them in Southeast Brazil, having been introduced for the aquarium trade and later released into nature accidentally or deliberately (Magalhães et al., 2005; Banci et al., 2013; Loureiro, 2015).

\section{IMPACTS}

Procambarus clarkii occupies an important position in the trophic structure of invaded environments, interacting with different trophic levels and changing the whole ecosystem functioning (Angeler et al., 2001; Dorn and Wojdak, 2004; Gherardi and Acquistapace, 2007; Cruz et al., 2008). Its flexible feeding strategy affects both lower and higher trophic levels by grazing on macrophytes and algae and preying on macroinvertebrates, fish fingerlings and tadpoles (Rodriguez et al., 2003; Rodriguez et al., 2005; Gherardi, 2006; Gherardi and Acquistapace, 2007).

Its efficiency on grazing macrophytes and extensive burrowing activity can alter freshwater environments, modifying them from macrophytedominated areas with clear water to phytoplankton dominated turbid areas (Rodriguez et al., 2003; Geiger et al., 2005; Matsuzaki et al., 2009). Macrophytes are particularly important to aquatic environments because they function as service providers and ecosystem engineers (Jones et al., 1994; 1997; Duarte, 2000) avoiding erosion, facilitating nutrient cycling and providing habitat to associated faunal communities (Duarte, 2000; de Groot et al., 2002; Gurnell et al., 2006), and serious changes may occur in aquatic environments if submersed plant species are overgrazed. Additionally, the burrowing behaviour might also cause river or channel bank erosion and increase water turbidity (Anastácio and Marques, 1997; Rodríguez et al., 2003). These changes in water characteristics alter aquatic ecosystems and are believed to induce cyanobacterial blooms (Yamamoto, 2010).

Furthermore, $P$. clarkii is one of the vectors of the crayfish plague, which is mostly asymptomatic in North American crayfish species such as $P$. clarkii, Orconectes limosus (Rafinesque, 1817) and Pacifastacus leniusculus (Dana, 1852), but lethal to crayfish from other regions (Souty-Grosset et al., 2006; Aquiloni et al., 2010; Longshaw, 2011). This disease, caused by Aphanomyces astaci, constitutes a remarkable threat to indigenous crayfish species, thus being one of the leading causes of native crayfish population decline in Europe (GutiérrezYurrita et al., 1999; Souty-Grosset et al., 2006; Holdich et al., 2009). Besides $A$. astaci, P. clarkii may carry many other pathogens, parasites, epibionts and diseases (see "Trophic ecology") that can affect other species, man included.

In addition to its influence on biodiversity, P. clarkii can also have a considerable economic impact. Primarily, costs of ecological damage and control measures can be highlighted (Kettunen et al., 2008). Costs of damage mainly occur in the agricultural, forestry, and fishery sectors. Regarding agricultural economic impacts specifically, crayfish infestation has caused serious damage to drainage systems as a consequence of its burrowing activities, causing important losses of rice yield (Sommer, 1984; Gaudé, 1986; Correia and Ferreira, 1995; Anastácio et al., 2000; 2005).

The red swamp crayfish is also a problem for fisheries once it spoils valuable fish caught in gillnets, damages fish nets and is considered a pest in many fish ponds (de Moor, 2002; Maezono and Miyashita, 2004).

\section{MANAgement AND CONTROL}

Procambarus clarkii invasion management options include the elimination or reduction of populations employing physical, chemical or biological methods and the use of legislation to prohibit the transport and release of specimens.

Removal campaigns using traps, fyke or seine nets and electro-fishing are commonly utilized as physical control, although they are often biased by crayfish size and sex (Westman et al., 1978; 1979). These methods are effective for population reduction but eradication is unlikely if populations are not restricted in range and size (Gherardi $e t$ al., 2011). Nevertheless, when physical control 
is to be used, it is better to invest in continued trapping then short-term intensive trapping, which can cause a feedback response in the population by stimulating faster maturation of juveniles and larger offspring per brood (Skurdal and Qvenild, 1986; Holdich et al., 1999). Drainage of ponds is also extensively used, especially in water bodies with dense populations, as well as diversion of rivers and construction of barriers; nonetheless, the efficiency of these methods is not yet confirmed, especially for pond drainage, since $P$. clarkii is resistant to drought due to its burrowing capacity (Kerby et al., 2005; Gherardi et al., 2011).

Another common practice to eradicate or control crayfish populations is with biocide, the most used being the application of xenobiotics, organophosphate, organochlorine, and pyrethroid insecticides (Cecchinelli et al., 2012). Chemical methods, however, were found to be ineffective because of their selective efficiency, with individual crayfish being differentially affected depending on size. In Italy, a laboratory test using the synthetic pyrethroid ciflutrin was found to be relatively effective (Quaglio et al., 2002). Chemical control of crayfish activity, aiming to induce temporary inactivity, was also tested without success in rice field ecosystems (Anastácio et al., 2000).

Besides being expensive, especially when applied to large areas, chemical control methods may have devastating impacts on native species and affect a wide range of organisms (Velez, 1980; Roqueplo and Hureaux, 1989). In fact, there are no selective biocides for crayfish or even crustaceans and development of resistance is frequent. Furthermore, the possibility of bioaccumulation and biomagnification cannot be discounted.

Biological control methods were also employed worldwide, including the use of fish predators, disease-causing organisms and microbes that produce toxins (Holdich et al., 1999; Frutiger and Müller, 2002) but the only method that has been successful so far is the use of predaceous fish like eels, burbots, perches and pikes (Westman, 1991; Aquiloni et al., 2010; Freeman et al., 2010). Nevertheless, biocontrol might be risky since it may lead to new species introductions and it is not specific to the target organism, possibly also affecting native organisms as well.

All methods mentioned above present environmental costs that can overcome their benefits. In fact, no single method for eradication is apparently successful. Thus, a combination of methods should be considered, such as trapping and the introduction of predatory fish species (Gherardi et al., 2011).

\section{FINAL REMARKS}

Species moved beyond the limits of their normal geographic ranges by human actions usually have strong ecological impacts (Witte $e t$ al., 1992; Parker, et al., 1999; Hall and Mills, 2000; Latini and Petrere, 2004) and the effects of biological invasion in freshwater habitats seem to be greater than in terrestrial ecosystems, especially because freshwater invasive species have a greater tendency to disperse (Sala et al., 2000; Beisel, 2001). Additionally, the importance of freshwater environments to humankind is enormous and modifications on its services will have a strong impact on human welfare.

Crayfish species have social, economic and ecological significance in several regions around the world, favouring their introduction into allochthonous areas (Reynolds and Souty-Grosset, 2012). Procambarus clarkii is among these successfully and widely translocated species, and its importance is mainly associated with aquaculture and the aquarium trade, being the most harvested crayfish species in the world and thus, the most intentionally introduced (Hobs and Lodge, 2010; Lodge et al., 2012).

The great concern regarding this species intensive introduction is that $P$. clarkii is a successful colonizer which has specific features that increase its invasive ability and favours its colonization success across the world, in different climatic and geographic areas; these features are its ecological plasticity, resistant gene pool to population changes, adaptation of its biology and life cycle to changing environmental conditions, high tolerance to salinity, oxygen and temperature variations, high somatic growth and reproductive output, short development time and flexible feeding strategy (Alcorlo et al., 2004; Gherardi, 2006; Jones et al., 2009). Therefore, after establishment, this species may quickly become a keystone species and cause serious changes in native plant and animal communities, altering water quality and sediment characteristics (Gherardi, 2007). 
In many countries, legislation designed to prevent crayfish spread is unsuccessful and causes conflicts due to the strong relationship between humans and crayfish that results from its recreational or commercial importance. However, once introduced into favorable habitats, $P$. clarkii is difficult to eliminate (Holdich, 1988). Different management and control methods were cited before although their applicability and efficiency is site-specific. Unsuccessful population control is frequent and apparently solutions cannot be standardized. Therefore, the most economically and environmentally effective technique is prevention of introduction and range expansion.

\section{ACKNOWLEDGMENTS}

This study was supported by the National Council for Scientific and Technological Development of the Brazilian government (CNPq), by the Coordination for the Perfecting of High Education Personnel (CAPES) and by the CAPES/COFECUB (international consortium Brazil - France) (Project: Freshwater limnetic ecosystems and conservation of freshwater crayfish of the genus Parastacus in southern Brazil - 8209/2012). The authors are grateful to $\mathrm{CNPq}$ for a productivity fellowship granted to PBA, to Julian Reynolds for English revision and intellectual contribution, to Kelly M. Gomes and Giovanna M. Cardoso for the illustration and to Felipe B. Ribeiro and Fábio V. Klug for pictures improvement.

\section{REFERENCES}

Alcorlo, P.; Geiger, W. and Otero, M. 2004. Feeding preferences and food selection of the red swamp crayfish, Procambarus clarkii, in habitats differing in food item diversity. Crustaceana, 77: 435-453.

Alcorlo, P.; Geiger, W. and Otero, M. 2008. Reproductive biology and life cycle of the invasive crayfish Procambarus clarkii (Crustacea: Decapoda) in diverse aquatic habitats of South-Western Spain: Implications for population. Fundamental and Applied Limnology, 173: 197-212.

Alderman, D.J. and Polglase, J.L. 1988. Pathogens, parasites and commensals. p. 167-212. In: D.M. Holdich and R.S. Lowery (eds), Freshwater Crayfish: biology, management and exploitation. London, Croom Helm.

Ameyaw-Akumfi, C. 1981. Courtship in the crayfish Procambarus clarkii (Girard) (Decapoda, Astacidea). Crustaceana, 40: 57-64.

Ameyaw-Akumfi, C. and Hazlett, B.A. 1975. Sex recognition in the crayfish Procambarus clarkii. Science, 190: $1225-1226$.
Amin, O.M. 1998. Marine flora and fauna of the eastern United States. Acanthocephala. NOAA Technical Report NMFS, 135: 1-27.

Anastácio, P.M.; Frias, A.F. and Marques, J.C. 2000. Impact of crayfish densities on wet seeded rice and the inneficiency of a non-ionic surfactant as an ecotechnological solution. Ecological Engineering, 15: 17-25.

Anastácio, P.M. and Marques, J.C. 1995. Population biology and production of the red swamp crayfish Procambarus clarkii (Girard) in the Lower Mondego river valley, Portugal. Journal of Crustacean Biology, 15: 156-168.

Anastácio, P.M. and Marques, J.C. 1997. Crayfish, Procambarus clarkii, effects on initial stages of rice growth in the lower Mondego River valley (Portugal). Freshwater Crayfish, 11: 608-617.

Anastácio, P.M.; Parente, V. and Correia, A.M. 2005. Crayfish effects on seeds and seedlings: identification and quantification of damage. Freshwater Biology, 50: 697-704

Angeler, D.G.; Sánchez-Carrillo, S.; García, G. and AlvarezCobelas, M. 2001. The influence of Procambarus clarkii (Cambaridae, Decapoda) on water quality and sediment characteristics in a Spanish floodplain wetland. Hydrobiologia, 464: 89-98.

Aquiloni, L.; Brusconi, S.; Cecchinelli, E.; Tricarico, E.; Mazza, G.; Paglianti, A. and Gherardi, F. 2010. Biological control of invasive populations of crayfish: the European eel (Anguilla anguilla) as a predator of Procambarus clarkii. Biological Invasions, 12: 3817-3824.

Aquiloni, L.; Ilhéu, M. and Gherardi, F. 2005. Habitat use and dispersal of the invasive crayfish Procambarus clarkii in ephemeral water bodies of Portugal. Marine and Freshwater Behaviour and Physiology, 38(4): 225-236.

Arrignon, J.C.V.; Huner, J.V. and Laurent, P.J. 1990. L'écrevisse Rouge des Marais. Paris, Maisonneuve et Larose, $87 \mathrm{p}$.

Baker, H.G. 1965. Characteristics and modes of origins of weeds. p. 147-172. In: H.G. Baker and G.L. Stebbins (eds), The Genetics of Colonizing Species. New York, U.S.A., Academic Press.

Banci, K.R.S.; Torello-Viera, N.F.; Marinho, O.S.; Calixto, P.O. and Marques, O.A.V. 2013. Predation of Rhinella ornata (Anura, Bufonidae) by the alien crayfish (Crustacea, Astacidae) Procambarus clarkii (Girard, 1852) in São Paulo, Brazil. Herpetology Notes, 6: 339341.

Barbaresi, S.; Fani, R.; Gherardi, F.; Mengoni, A. and Souty-Grosset, C. 2003. Genetic variability in European populations of an invasive American crayfish: preliminary results. Biological Invasions, 5: 269-274.

Barbaresi, S. and Gherardi, F. 2000. The invasion of the alien crayfish Procambarus clarkii in Europe, with particular reference to Italy. Biological invasions, 2: 259-264.

Barbaresi, S. and Gherardi, F. 2006. Experimental evidence for homing in the red swamp crayfish, Procambarus clarkii. Bulletin Francais de la peche et la pisciculture, 380-381: 1145-1154. 
Barbaresi, S.; Gherardi, F.; Mengoni, A. and Souty-Grosset, C. 2007. Genetics and invasion biology in fresh waters: a pilot study of Procambarus clarkii in Europe. p 381400. In: F. Gherardi (ed), Biological invaders in inland waters: Profiles, distribution, and threats. Dordrecht, The Netherlands, Springer.

Barbaresi, S.; Santini, G.; Tricarico, E. and Gherardi, F. 2004. Ranging behaviour of the invasive crayfish Procambarus clarkii (Girard). Journal of Natural History, 38: 2821-2832.

Baumgartner, W.A; Hawke, J.P.; Bowles, K.; Varner, P.W. and Hasson, K.W. 2009. Primary diagnosis and surveillance of white spot syndrome virus in wild and farmed crawfish (Procambarus clarkii, P. zonangulus) in Louisiana, USA. Diseases of Aquatic Organisms, 85: 15-22.

Beisel, J.N. 2001. The elusive model of a biological invasion process: time to take differences among aquatic and terrestrial ecosystems into account? Ethology Ecology \& Evolution, 13: 193-195.

Bovbjerg, R.V. 1956. Some factors affecting aggressive behavior in crayfish. Physiological Zoology, 29: 127-136.

Buck, T.L.; Breed, G.A.; Pennings, S.C.; Chase, M.E.; Zimmer, M. and Carefoot, T.H. 2003. Diet choice in an omnivorous salt-marsh crab: different food types, body size, and habitat complexity. Journal of Experimental Marine Biology and Ecology, 292: 103-116.

Campos, E. and Rodríguez-Almaraz, G.A. 1992. Distribution of the Red Swamp Crayfish Procambarus clarkii (Girard, 1852) (Decapoda: Cambaridae) in Mexico: An Update. Journal of Crustacean Biology, 12: 627-630.

Carlton, J.T. 1996. Pattern, process, and prediction in marine invasion ecology. Biological Conservation, 78: 97106.

Cecchinelli, E.; Aquiloni, L.; Maltagliati, G.; Orioli, G.; Tricarico, E. and Gherardi, F. 2012. Use of natural pyrethrum to control the red swamp crayfish Procambarus clarkii in a rural district of Italy. Pest Management Science, 68: 839-844.

Cerenius, L.; Söderhäll, K.; Persson, M. and Ajaxon, R. 1988. The crayfish plague fungus, Aphanomyces astaci - diagnosis, isolation and pathobiology. Freshwater Crayfish, 7: 131-144.

Chang, P.; Chen, H. and Wang, Y. 1998. Detection of white spot syndrome associated baculovirus in experimentally infected wild shrimp, crab and lobsters by in situ hybridization. Aquaculture, 164(1-4): 233-242.

Chucholl, C. 2011. Population ecology of an alien "warm water" crayfish (Procambarus clarkii) in a new cold habitat. Knowledge and Management of Aquatic Ecosystems, 401: 29p1-29p21.

Clark, W.H. and Ralston, G.L. 1976. First record of crayfish from Baja California, Mexico (Decapoda, Astacidae). Crustaceana, 30: 106-107.

Clark, W.H. and Wroten, J. W. 1978. First record of the crayfish, Procambarus clarkii, from Idaho, U.S.A (Decapoda, Cambaridae). Crustaceana, 35: 317-319.
Cohen, A.N. and Carlton, J.T. 1995. Biological study. Nonindigenous aquatic species in a United States estuary: a case study of the biological invasions of the San Francisco Bay and Delta. Washington, DC, US Fish and Wildlife Service.

Copp, N. H. 1986. Dominance hierarchies in the crayfish Procambarus clarkii (Girard, 1852) and the question of learned individual recognition (Decapoda, Astacidea). Crustaceana, 51: 9-23.

Correia, A.M. 2002. Niche breadth and trophic diversity: feeding behavior of the red swamp crayfish (Procambarus clarkii) towards environmental availability of aquatic macroinvertebrates in a rice field (Portugal). Acta Oecologica, 23: 421-429.

Correia, A.M. and Ferreira, Ó. 1995. Burrowing behavior of the introduced red swamp crayfish Procambarus clarkii (Decapoda: Cambaridae) in Portugal. Journal of Crustacean Biology, 15: 248-257.

Crandall, K.A. and Buhay, J.E. 2008. Global diversity of crayfish (Astacidae, Cambaridae, and ParastacidaeDecapoda) in freshwater. Hydrobiologia, 595: 295-301.

Cruz, M.J. and Rebelo, R. 2005. Vulnerability of Southwest Iberian amphibians to an introduced crayfish, Procambarus clarkii. Amphibia-Reptilia, 26: 293-303.

Cruz, M.J.; Segurado, P.; Sousa, M. and Rebelo, R. 2008. Collapse of the amphibian community of the Paul do Boquilobo Natural Reserve (central Portugal) after the arrival of the exotic American crayfish Procambarus clarkii. Journal of Herpetology, 18: 197-204.

D'Abramo, L.R. and Robinson, E.H. 1989. Nutrition of crayfish. Aquatic Science, 1: 711-728.

D’Itri, F.M. 1997. Zebra Mussels and Aquatic Nuisance Species. Ann Arbor, University of Michigan Press, 648p.

Dehus, P.; Phillipson, S.; Bohl, E.; Oidtmann, B.; Keller, M. and Lechleiter, S. 1999. German conservation strategies for native crayfish species with regard to alien species. Crustacean Issues, 11: 149-159.

Delibes, M. and Adrian, I. 1987. Effects of crayfish introduction on Otter Lutra lutra food in the Donana National Park, Spain. Biological Conservation, 42: 153159.

Diéguez-Uribeondo, J.; Cerenius, L. and Söderhäll, K. 1994. Saprolegnia parasitica and its virulence on three different species of crayfish. Aquaculture, 120: 219-228.

Diéguez-Uribeondo, J.; Huang, T.S.; Cerenius, L. and Söderhäll, K. 1995. Physiological adaptation of an Aphanomyces astaci strain isolated from the warm-water crayfish Procambarus clarkii. Mycological Research, 99: 574-578.

Dick, J.T.A.; Elwood, R.W. and Montgomery, W.I. 1995. The behavioural basis of a speciesreplacement: differential aggression andpredation between the introducedGammarus pulex and the native $G$. duebenicelticus (Amphipoda). Behavioral Ecology and Sociobiology, 37: 393-398.

Dorn, N. and Wojdak, J. 2004. The role of omnivorous crayfish in littoral communities. Oecologia, 140: 150-159. 
Dörr, A.J.M.; La Porta, G.; Pedicillo, G. and Lorenzoni, M. 2006. Biology of Procambarus clarkii (Girard, 1852) in Lake Trasimeno. Bulletin Français de la Pêche et de la Pisciculture, 380: 1155-1167.

Duarte, C.M. 2000. Marine biodiversity and ecosystem services: an elusive link. Journal of Experimental Marine Biology and Ecology, 250: 117-131.

Dümpelmann, C.; Bonacker, F. and Häckl, M. 2009. Erstnachweis des Roten Amerikanischen Sumpfkrebses Procambarus clarkii (Decapoda: Cambaridae) in Hessen. Lauterbornia, 67: 39-47.

Dunn, J.C.; Mc Clymont, H.E.; Christmas, M. and Dunn, A.M., 2009. Competition and parasitism in the native white clawed crayfish Austropotamobius pallipes and the invasive signal crayfish Pacifastacus leniusculus in the UK. Biological Invasions, 11: 315-324.

Edgerton, B.F.; Evans, L.H.; Stephens, F.J. and Overstreet, R.M. 2002. Synopsis of freshwater crayfish diseases and commensal organisms. Aquaculture, 206: 57-135.

El Zein, G. 2005. Introduction and impact of the crayfish Procambarus clarkii in the Egyptian Nile. L'Astaciculteur de France, 84: 1-12.

Etges, F.J. 1953. Studies on the Life Histories of Maritrema obstipum (Van Cleave and Mueller, 1932) and Levinseniella amnicolae n. sp. (Trematoda: Microphallidae). The Journal of Parasitology, 39(6): 643-662.

Feminella, J.W. and Resh, V.H. 1989. Submerged macrophytes and grazing crayfish: an experimental study of herbivory in California freshwater marsh. Holartic Ecology, 12: 1-8.

Figler, M.H.; Blank, G.S. and Peeke, H.V.S. 1997. Maternal aggression and post-hatch care in red swamp crayfish, Procambarus clarkii (Girard): the influences of presence of offspring, fostering and maternal molting. Marine and Freshwater Behaviour and Physiology, 30: 173-194.

Figler, M.H.; Finkelstein, J.E.; Twum, M. and Peeke, H.V.S. 1995. Intruding male red swamp crayfish, Procambarus clarkii, immediately dominate members of established communities of smaller, mixed-sex conspecifics. Aggressive Behavior, 21(3): 225-236.

Figler, M.H.; Twum, M.; Finkelstein, J.E. and Peeke, H.V.S. 1995. Maternal aggression in red swamp crayfish (Procambarus clarkii, Girard): the relation between reproductive status and outcome of aggressive encounters with male and female conspecifics. Behaviour, 132: 107-125.

Fishar, D.M.R. 2006. Red swamp crayfish (Procambarus clarkii) in River Nile, Egypt. Biodiversity Monitoring and Assessment Project. Cairo, Ministry of State for Egyptian Environmental Affairs Agency.

Foster, J. and Harper, D. 2007. Status and ecosystem interactions of the invasive Louisianan red swamp crayfish Procambarus clarkii in East Africa. p. 91-101. In: F. Gherardi (ed), Biological Invaders in Inland Waters: Profiles, distribution, and threats. Rotterdam, Springer.

Freeman, M.A.; Turnbull, J.F.; Yeomans, J.F. and Bean, C.W. 2010. Prospects for management strategies of invasive crayfish populations with an emphasis on biological control. Aquatic Conservation: Marine and Freshwater Ecosystems, 20: 211-223.
Frutiger, A. and Müller, R. 2002. Controlling unwanted Procambarus clarkii populations by fish predation. Freshwater Crayfish, 13: 309-315.

Gamradt, S.C.; Katz, L.B. and Anzalone, C.B. 1997. Aggression by non-native crayfish deters breeding in California newts. Conservation Biology, 11: 793-796.

Gaudé, P. 1986. Ecology and production of Louisiana red swamp crawfish Procambarus clarkii in Southern Spain. Freshwater Crayfish, 6: 111-130.

Geiger, W.; Alcorol, P.; Baltanás, A. and Montes, C. 2005. Impact of an introduced Crustacean on the trophic webs of Mediterranean wetlands. p. 49-73. In: L. Capdevila-Arguëlles and B. Zilletti (eds), Issues in Bioinvasion Science. Berlin, Springer-Verlag.

Gelder, S.R. 1999. Zoogeography of branchiobdellidans (Annelida) and temnocephalidans (Platyhelminthes) ectosymbiotic on freshwater crustaceans, and their reactions to one another in vitro. Hydrobiologia, 406: 21-31.

Gelder, S.R.; Delmastro, G.B. and Rayburn, J.N. 1999. Distribution of native and exotic branchiobdellidans (Annelida: Clitellata) on their respective crayfish hosts in northern Italy, with the first record of native Branchiobdella species on an exotic North American crayfish. Journal of Limnology, 58(1): 20-24.

Gherardi, F. 2001. Behaviour. p. 258-290. In: D.M. Holdich (ed.), Biology of Freshwater Crayfish. Oxford, Blackwell Science.

Gherardi, F. 2006. Crayfish invading Europe: the case study of Procambarus clarkii. Marine and Freshwater Behaviour and Physiology, 39: 175-191.

Gherardi, F. 2007. Understanding the impact of invasive crayfish. p. 507-542. In: F. Gherardi (ed), Biological Invaders in Inland Waters: Profiles, distribution, and threats. Rotterdam, Springer.

Gherardi, F. 2011. Crayfish. p. 129-35. In: D. Simberloffand and M. Rejmánek (eds), Encyclopedia of Biological Invasions. Berkeley, University of California Press.

Gherardi, F. and Acquistapace, P. 2007. Invasive crayfish in Europe: the impact of Procambarus clarkii on the littoral community of a Mediterranean lake. Freshwater Biology, 52: 1249-1259.

Gherardi, F.; Acquistapace, P.; Tricarico, E. and Barbaresi, S. 2002a. Ranging behaviour of the red swamp crayfish in an invaded habitat: the onset of hibernation. Freshwater Crayfish, 14: 330-337.

Gherardi, F.; Aquiloni, L.; Diéguez-Uribeondo, J. and Tricarico, E. 2011. Managing invasive crayfish: is there a hope? Aquatic Sciences, 73: 185-200.

Gherardi, F. and Barbaresi, S. 2000. Invasive crayfish: activity patterns of Procambarus clarkii in the rice fields of the Lower Guadalquivir (Spain). Archiv für Hydrobiologie, 150: 153-168.

Gherardi, F.; Barbaresi, S. and Salvi, G. 2000. Spatial and temporal patterns in the movement of Procambarus clarkii, an invasive crayfish. Aquatic Science, 62: 179193. 
Gherardi F.; Souty-Grosset C.; Vogt G.; Diéguez-Uribeondo J. and Crandall K.A. 2010. Treatise on Zoology Anatomy, Taxonomy, Biology. The Crustacea, Brill Leiden-Boston. Chapter Infraorder Astacidea Latreille, 1802 Volume 9 (61) Part A: 269-423.

Gherardi, F.; Tricarico, E. and Ilhéu, M. 2002b. Movement patterns of an invasive crayfish, Procambarus clarkii, in a temporary stream of southern Portugal. Ethology Ecology \& Evolution, 14: 183-197.

de Groot, R.S.; Wilson, M.A. and Boumans, R.M.J. 2002. A typology for the classification, description and valuation of ecosystem functions, goods and services. Ecology Economics, 41: 393-408.

Gurnell, A.M.; Oosterhout, M.P.V.; Vlieger, B.D. and Goodson, J.M. 2006. Reach-scale interactions between aquatic plants and physical habitat: River Frome, Dorset. River Research and Applications, 22: 667-680.

Gutiérrez-Yurrita, P.J.; Martínez, J.M.; Bravo-Utrera, M.Á.; Montes, C.; Ilhéu, M. and Bernardo, J.M. 1999. The status of crayfish populations in Spain and Portugal. p. 161-192. In: F. Gherardi and D.M. Holdich (eds), Crayfish in Europe as Alien Species: How to Make the Best of a Bad Situation? Rotterdam, A.A. Balkema.

Gutiérrez-Yurrita, P. J.; Sancho, G.; Bravo, M.Á.; Baltanás, Á. and Montes, C. 1998. Diet of the red swamp crayfish Procambarus clarkii in natural ecosystems of the Donana National Park temporary freshwater marsh (Spain). Journal of Crustacean Biology, 18: 120-127.

Gydemo, R.; Westin, L. and Nissling, A. 1990. Predation on larvae of the noble crayfish, Astacus astacus. Aquaculture, 86: 155-161.

Habsburgo-Lorena, A.S. 1979. Crayfish situation in Spain. Crayfish News, 3: 1-2.

Hall, S.R. and Mills, E.L. 2000. Exotic species in large lakes of the world. Aquatic Ecosystem Health and Management, 3: 105-135.

Hänfling, B.; Edwards, F. and Gherardi, F. 2011. Invasive alien Crustacea: dispersal, establishment, impact and control. BioControl, 56: 573-595.

Harper, D.M.; Smart, A.C.; Coley, S.; Schmitz, S.; de Beauregard, A.G.; North, R.; Adams, C.; Obade, P. and Kamau, M. 2002. Distribution and abundance of the Louisiana red swamp crayfish Procambarus clarkii Girard at Lake Naivasha, Kenya between 1987 and 1999. Hydrobiologia, 488: 143-151.

Henttonen, P. and Huner, J.V. 1999. The introduction of alien species of crayfish in Europe: A historical introduction. p. 13-22. In: F. Gherardi and D.M. Holdich (eds), Crayfish in Europe as Alien Species: How to Make the Best of a Bad Situation? Rotterdam, A.A. Balkema.

Henntonen, P.; Huner, J. and Lindqvist, O.V. 1994. Occurrence of Psorospermium sp. in several North American crayfish species, with comparative notes on Psorospermium haeckeli in European crayfish, Astacus astacus. Aquaculture, 120: 209-218.
Hobbs, H.H. 1972. Biota of Freshwater EcosystemsIdentification Manual 9: Crayfishes (Astacidae) of North and Middle America: Water Pollution Control Research Series. Washington, DC, US Environmental Protection Agency.

Hobbs, H.H. 1974. Synopsis of the families and genera of crayfishes (Crustacea, Decapoda). Smithsonian Contributions to Zoology, 164: 1-32.

Hobbs, H.H. 1981. The crayfishes of Georgia. Smithsonian Contributions to Zoology, 318: 1-549.

Hobbs, H.H. 1988. Crayfish distribution, adaptive radiation, and evolution. p. 52-82. In: D.M. Holdich and R.S. Lowery (eds), Freshwater Crayfish: biology, management and exploitation. London, Croom Helm.

Hobbs, H.H. and Jass, J.P. 1989. The Crayfishes and Shrimp of Wisconsin (Cambaridae, Palaemonidae). Milwaukee, WI, Milwakee public museum, 177p.

Hobbs, H.H.; Jass, J.P. and Huner, J.V. 1989. A review of global crayfish introductions with particular emphasis on two North American species (Decapoda, Cambaridae). Crustaceana, 56: 299-316.

Hobbs, H.H. and Lodge, D.M. 2010. Decapoda. p. 901968. In: J.H. Thorp and A.P. Covich (eds), Ecology and Classification of North American Freshwater Invertebrates. London, Elsevier Inc.

Holdich, D.M. 1988. The dangers of introducing alien animals with particular reference to crayfish. Freshwater Crayfish, 7: 15-30.

Holdich, D.M. 1999. The negative effects of established crayfish populations. p. 31-48. In: F. Gherardi and D.M. Holdich (eds), Crayfish in Europe as Alien Species: How to Make the Best of a Bad Situation? Rotterdam, A.A. Balkema.

Holdich, D.M.; Gydemo, R. and Rogers, W.D. 1999. A review of possible methods for controlling alien crayfish populations. p. 245-270. In: F. Gherardi and D.M. Holdich (eds), Crayfish in Europe as Alien Species: How to Make the Best of a Bad Situation? Rotterdam, A.A. Balkema.

Holdich, D.M. and Lowery, R.S. 1988. Freshwater crayfish: biology, management and exploitation. London, Croom Helm, 440p.

Holdich, D.M.; Reynolds, J.D.; Souty-Grosset, C. and Sibley, P.J. 2009. A review of the ever increasing threat to European crayfish from non-indigenous crayfish species. Knowledge and Management of Aquatic Ecosystems, 11: 1-46.

Holt, P.C. 1975. The branchiobdellid (Annelida: Clitellata) associates of Astacoidean crawfishes. Freshwater Crayfish, 2: 337-346.

Huner, J.V. 1981. Information about the biology and culture of the red swamp crawfish, Procambarus clarkii (Girard, 1852) (Decapoda, Cambaridae) for fisheries managers in Latin America. Anales del Instituto de Ciencias del Mar y Limnologia, 8: 43-50.

Huner, J.V. 1986. Crawfish Introductions Affect Louisiana Industry. Crawfish Tales, 5: 16-18. 
Huner, J.V. 1988. Procambarus in North America and elsewhere. p. 239-261. In: D.M. Holdich and R.S. Lowery (eds), Freshwater Crayfish: biology, management and exploitation, London, Croom Helm.

Huner, J.V. 1994. Freshwater crayfish culture. p. 5-89. In: J.V. Huner (ed), Freshwater Crayfish Aquaculture in North America, Europe and Australia. Binghamton, NY, Food Products Press.

Huner, J.V. 2002. Procambarus. p. 541-574. In: D.M. Holdich (ed), Biology of Freshwater Crayfish. Oxford, Blackwell Scientific Press.

Huner, J.V. and Avault, J.W. 1979. Introductions of Procambarus spp. Freshwater Crayfish, 4: 191-194.

Huner, J.V. and Barr, J.E. 1991. Red swamp crayfish: biology and exploitation. The Louisiana Sea Grant College Program, Center for Wetland Resources. Baton Rouge, LA, Louisiana State University, 148p.

Ilhéu, M. and Bernardo, J.M. 1993. Aspects of trophic ecology of red swamp crayfish (Procambarus clarkii, Girard) in Alentejo, south of Portugal. p. 417-423. In: Actas VI Congreso Español de Limnologia, Granada, Spain.

Ilhéu, M. and Bernardo, J.M. 1995. Trophic ecology of red swamp crayfish Procambarus clarkii (Girard)preferences and digestibility of plantfoods. Freshwater Crayfish, 10: 132-139.

Ilhéu, M.; Bernardo, J.M. and Fernandes, S. 2007. Predation of invasive crayfish on aquatic vertebrates: the effect of Procambarus clarkii on fish assemblages in Mediterranean temporary streams. p. 543-558. In: F. Gherardi (ed), Biological invaders in inland waters: profiles, distribution, and threats. Rotterdam, Springer.

Issa, F.A.; Adamson, D.J. and Edwards, D.H. 1999. Dominance hierarchy formation in juvenile crayfish Procambarus clarkii. The Journal of Experimental Biology, 202: 3497-3506.

Johnson, J.E. 1986. Inventory of Utah Crayfish with Notes on Current Distribution. Great Basin Naturalist, 46: 625-631.

Johnson, L.E. and Carlton, J.T. 1996. Post-establishment spread in large-scale invasions: dispersal mechanisms of the zebra mussel (Dreissena polymorpha). Ecology, 77: 1686-1687.

Jones, C.G.; Lawton, J.H. and Shachak, M. 1994. Organisms as ecosystems engineers. Oikos, 69: 373-386.

Jones, C.G.; Lawton, J.H. and Shachak, M. 1997. Positive and negative effects of organisms as physical ecosystems engineers. Ecology, 78: 1946-1957.

Jones, J.; Rasamy, J.; Harvey, A.; Toon, A.; Oidtmann, B.; Randrianarison, M.H.; Raminosoa, N. and Ravoahangimalala, O.R. 2009. The perfect invader: a parthenogenic crayfish poses a new threat to Madagascar's freshwater biodiversity. Biological Invasions, 11: 14751482.

Kawai, T. and Kobayashi, Y. 2005. Origin and current distribution of the alien crayfish, Procambarus clarkii (Girard, 1852) in Japan. Crustaceana, 78: 1143-1149.
Kerby, J.L.; Riley, S.P.D.; Kats, L.B. and Wilson, P. 2005. Barriers and flow as limiting factors in the spread of an invasive crayfish (Procambarus clarkii) in southern California streams. Biological Conservation, 126: 402409.

Kettunen, M.; Genovesi, P.; Gollasch, S.; Pagad, S.; Starfinger, U.; ten Brink, P. and Shine, C. 2008. Technical support to EU strategy on invasive species (IAS) - Assessment of the impacts of IAS in Europe and the EU (final module report for the European Commission). Brussels, Belgium, Institute for European Environmental Policy (IEEP), $124 \mathrm{p}$.

Kolar, C.S. and Lodge, D.M. 2001. Progress in invasion biology: predicting invaders. Trends in Ecology \& Evolution, 16: 199-204.

Kreiser, B.R.; Mitton, J.B. and Woodling, J.D. 2000. Single versus multiple sources of introduced populations identified with molecular markers: a case study of a freshwater fish. Biological Invasions, 2: 295-304.

Lane, M.A.; Barsanti, M.C.; Santos, C.A.; Yeung, M.; Lubner, S.J. and Weil, G.J. 2009. Human Paragonimiasis in North America following Ingestion of Raw Crayfish. Clinical Infectious Diseases, 49: e55-61.

Lantz, K.E. 1974. Acanthocephalan occurrence in cultured red crawfish. Proceedings of the 27th Annual Conference of the Southeastern Association of Game and Fish Commissioners, 1973: 735-738.

Latini, A.O. and Petrere Jr., M. 2004. Reduction of a native fish fauna by alien species: an example from Brazilian freshwater tropical lakes. Fisheries Management and Ecology, 11: 71-79.

Lee, C.E. 2002. Evolutionary genetics of invasive species. Trends in Ecology and Evolution, 17: 386-391.

Lewis, M.A. 1998. Variability, patchiness and jump dispersal in the spread of an invading population. $\mathrm{p}$. 46-69. In: D. Tilman and P. Kareiva (eds), Spatial Ecology: The Role of Space in Population Dynamics and Interspecific Interactions. Princeton, USA, Princeton University Press.

Li, J.L.; Dong, Z.G.; Li, Y.S. and Wang, C.H. 2007. Invasive Aquatic Species in China. Shanghai, Department of Nature and Ecology Conservation, 104p.

Li, Y.; Guo, X.; Cao, X.; Deng, W.; Luo, W. and Wang, W. 2012. Population Genetic Structure and PostEstablishment Dispersal Patterns of the Red Swamp Crayfish Procambarus clarkii in China. PLoS ONE 7(7): e40652. doi:10.1371/journal.pone.0040652

Li, S.C.; Xu, Y.X.; Du, L.Q.; Yi, X.L.; Men, X.D. and Xie, J.Y. 2005. Investigation on and analysis of alien invasions in Chinese farming industry. Chinese Agricultural Science Bulletin, 21: 156-159.

Lindqvist, O.V. and Huner, J.V. 1999. Life history characteristics of crayfish: What makes some of them good colonizers? p. 23-30. In: F. Gherardi and D.M. Holdich (eds), Crayfish in Europe as alien species: How to make the best of a bad situation? Rotterdam, A.A. Balkema. 
Liu, G.; Zhou, L.; Li, X. and Lu, D. 2013. Population Genetic Structure of the Invasive Red Swamp Crayfish in China Revealed by ITS1 Variation. Biochemical Genetics, 51(11-12): 841-52.

Lodge, D.M.; Deines, A.; Gherardi, F.; Yeo, D.C.J.; Arcella, T.; Baldridge, A.K.; Barnes, M.A.; Chadderton, W.L.; Feder, J.L.; Gantz, C.A. et al. 2012. Global Introductions of Crayfishes: Evaluating the Impact of Species Invasions on Ecosystem Services. Annual Review of Ecology, Evolution, and Systematics, 43: 449-472.

Lodge, D.M.; Mungai, B.N.; Rosenthal, S.K.; Mkoji, G.M. and Mavuti, K.M. 2005. Louisiana crayfish (Procambarus clarkii) (Crustacea: Cambaridae) in Kenyan ponds: nontarget effects of a potential biological control agent for schistosomiasis. African Journal of Aquatic Science, 30: 119-124.

Lodge, D.M.; Taylor, C.A.; Holdich, D.M. and Skurdal, J. 2000. Nonindigenous crayfish threaten North American freshwater biodiversity: lessons from Europe. Fisheries, 25: 7-19.

Longshaw, M. 2011. Diseases of crayfish: a review. Journal of Invertebrate Pathology, 106: 54-70.

Loureiro, T.G.; Anastácio, P.M.S.G.; Bueno, S.L.S.; Araujo, P.B.; Souty-Grosset, C. and Almerão, M.P. Distribution, introduction pathway and invasion risk analysis of the North American crayfish Procambarus clarkii (Crustacea, Decapoda, Cambaridae) in Southeast Brazil. Journal of Crustacean Biology, 35(1): 88-96.

Lotz, J.M.; Corkum, K.C. 1983. Studies on the life history of Sogandaritrema progeneticus (Digenea: Microphallidae). Journal of Parasitology, 69(5): 918-921.

Lowe, M. 1956. Dominance-subordinance relationships in the crayfish Cambarellus shufeldti. Tulane Studies in Zoology, 4: 139-170.

Mac Eachern, D.; Mc Cullough, J.; Duchin, J.; Tran, M.; Mac Donald, K.; Marfin, A.; Jones, J.; Newton, A.; Tarr, C.; Talkington, D.; Mintz, E.; Barzilay, E. J.; Kay, M. and Cartwright, E. 2010. Notes from the field: Vibrio mimicus infection from consuming crayfish. Morbidity and Mortality Weekly Report, 59 (42): 1374.

Maezono, Y. and Miyashita, T. 2004. Impact of exotic fish removal on native communities in farm ponds. Ecological Research, 19: 263-67.

Magalhães, C.; Bueno, S.L.S.; Bond-Buckup, G. Valenti, W.C.; Silva, H.L.M.; Kiyohara, F.; Mossolin, E.C. and Rocha, S.S. 2005. Exotic species of freshwater decapod crustaceans in the state of São Paulo, Brazil: records and possible causes of their introduction. Biodiversity and Conservation, 14: 1929-1945.

Marchetti, M.P.; Moyle, P.B. and Levine, R. 2004. Invasive species profiling? Exploring the characteristics of non-native fishes across invasion stages in California. Freshwater Biology, 49(5): 646-661.

Matsuzaki, S.S.; Usio, N.; Takamura, N. and Washitani, I. 2009.Contrasting impacts of invasive engineers on freshwater ecosystems: an experiment and meta-analysis. Oecologia, 158: 673-686.
Mikkola, H. 1996. Alien freshwater crustacean and indigenous mollusk species with aquaculture potential in eastern and southern Africa. Southern African Journal of Aquatic Sciences, 22: 90-99.

Mito, T. and Uesugi, T. 2004. Invasive Alien Species in Japan: The Status Quo and the New Regulation for Prevention of their Adverse Effects. Global Environmental Research, 8: 171-191.

Nalepa, T.F. and Schloesser, D.W. 1993. Zebra Mussels: Biology, Impacts and Control. London, Lewis Publishers, 832p.

Noblitt, S.B.; Payne, J.F. and Delong, M. 1995. A comparative study of selected physical aspects of the eggs of the crayfish Procambarus clarkii (Girard, 1852) and $P$. zonangulus Hobbs \& Hobbs, 1990 (Decapoda, Cambaridae). Crustaceana, 68(5): 575-582.

Oluoch, A.O. 1990. Breeding biology of the Louisiana red swamp crayfish Procambarus clarkii Girard in Lake Naivasha, Kenya. Hydrobiologia, 208: 85-92.

Overstreet, R.M.; Heard R.W. and Lotz, J.M. 1992. Microphallus fonti sp. n. (Digenea: Microphallidae) from the red swamp crawfish in southern United States. Memórias do Instituto Oswaldo Cruz, 87: 175178.

Parker, I.M.; Simberloff, D.; Lonsdale, W.M.; Goodell,K.; Wonham, M.; Kareiva, P.M.; Williamson, M.H.; Von Holle, B.; Moyle, P.B.; Byers, J.E. and Goldwasser, L. 1999. Impact: toward a framework for understanding the ecological effects of invaders. Biological Invasions, 1: 3-19.

Parkyn, S.M.; Kevin, J.C. and Hicks, B.J. 2001. New Zealand stream crayfish: functional omnivorous but trophic predators? Freshwater Biology, 46: 641-652.

Paulson, E.L. and Martin, A.P. 2013. Discerning invasion history in an ephemerally connected system: landscape genetics of Procambarus clarkii in Ash Meadows, Nevada. Biological Invasions, 16: 1719-1734.

Peña, J.С. 1994. Morphometric relationships and yield in Costa Rican Procambarus clarkii (Decapoda: Cambaridae). Revista de Biología Tropical, 42: 743744.

Penn, G.H. 1943. A Study of the Life History of the Louisiana Red-Crawfish, Cambarus clarkii Girard. Ecology, 24(1): 1-18.

Procop, G.W. 2009. North American paragonimiasis (caused by Paragoninus kellicotti) in the context of global paragonimiasis. Clinical Microbiology Reviews, 22(3): 415-446.

Quaglio, F.; Malvisi, J.; Maxia, M.; Morolli, C.; della Rocca, G. and Di Salvo, A. 2002. Toxicity of the synthetic pyrethroid ciflutrin to the red swamp crayfish (Procambarus clarkii). Freshwater Crayfish, 13: 431-436.

Rafinesque, C.F. 1817. Synopsis of four new genera and 10 new species of Crustacea found in the United States. American Monthly Magazine and Critical Review, 2: 4043. 
Ragan, M.A.; Goggin, C.; Cawthorn, J.R.; Cerenius, L.; Jamieson, A.V.; Plourde, S.M.; Rand, T.G. and Söderhäll, K. 1996. A novel clade of protistan parasites near the animal-fungal divergence. Proceedings of the National Academy of Sciences, 93: 11907-11912.

Reynolds, J.D. and Souty-Grosset, C. 2012. Management of freshwater biodiversity, Crayfish as bioindicators, 384p. Cambrige, Cambridge University Press.

Rodríguez, C.F.; Bécares, E. and Fernández-Aláez, M. 2003. Shift from clear to turbid phase in Lake Chozas (NW Spain) due to the introduction of American red swamp crayfish (Procambarus clarkii). Hydrobiologia, 506: 421-26.

Rodríguez, C.F.; Bécares, E.; Fernández-Aláez, M. and Fernández-Aláez, C. 2005. Loss of diversity and degradation of wetlands as a result of introducing exotic crayfish. Biological Invasions, 7: 75-85.

Roqueplo, C. And Hureaux, N. 1989. Ecrevisses: Le point. Aqua Revue, 27: 31-36.

Ruiz, G.M.; Carlton, J.T.; Grosholz, E.D. and Hines, A.H. 1997. Global invasions of marine and estuarine habitats by non-indigenous species: Mechanisms, extent, and consequences. American Zoologist, 37: 621-632.

Sala, O.E.; Chapin III, F.S.; Armesto, J.J.; Berlow, E.; Bloomfield, J.; Dirzo, R.; Huber-Sannwald, E.; Huenneke, L.; Jackson, R.B.; Kinzig, A.; Leemans, R.; Lodge, D.M.; Mooney, H.A.; Oesterheld, M.; Poff, N.L.; Sykes, M.T.; Walker, B.H.; Walker, M. and Wall, D.H. 2000. Biodiversity scenarios for the year 2100 . Science, 287: 1770-1774.

Savini, D.; Occhipinti-Ambrogi, A.; Marchini, A.; Tricarico, E.; Gherardi, F.; Olenin, S. and Gollasch, S. 2010. The top 27 animal alien species introduced into Europe for aquaculture and related activities. Journal of Applied Ichthyology, 26:1-7.

Silva, H.L.M. and Bueno, S.L.S. 2005. Population size estimation of the exotic crayfish Procambarus clarkii (Girard) (Crustacea, Decapoda, Cambaridae) in the Alfredo Volpi City Park, São Paulo, Brazil. Revista Brasileira de Zoologia, 22: 93-98.

Skurdal, J. and Qvenild, T. 1986. Growth, maturity and fecundity of Astacus astacus in Lake Steinsfjorden, S. E. Norway. Freshwater Crayfish, 6: 182-186.

Smart, C.A.; Harper, D.M.; Malaisse, F.; Schmitz, S.; Coley, S. and Beauregard, A.C.G. 2002. Feeding of the exotic Louisiana red swamp crayfish, Procambarus clarkii (Crustacea, Decapoda), in an African tropical lake: Lake Naivasha, Kenya. Hydrobiologia, 488: 129-142.

Soes, M. and van Eekelen, R. 2006. Rivierkrefeten, een oprukkend problem? De Levede Natur, 107: 56-59.

Sogandares-Bernal, F. 1965. Parasites from Louisiana crayfishes. Tulane Studies in Zoology, 12: 79-85.

Sommer, T.R. 1984. The biological response of the crayfish Procambarus clarkii to transplantation into California ricefields. Aquaculture, 41: 373-384.

Souty-Grosset, C.; Holdich, D.M.; Noel, P.Y.; Reynolds, J.D. and Haffner, P. 2006. Atlas of crayfish in Europe. Paris, Publications Scientifiques du Muséum national d'Histoire naturelle, Patrimoines Naturels 64, 188p.
Sukô, T. 1953. Studies on the development of the crayfish. I. The development of secondary sex characters in appendages. The Science Reports of Saitama University, 1B: 77-96.

Taketomi, Y.; Murata, M. and Miyawaki, M. 1990. Androgenic gland and secondary sexual characters in the crayfish Procambarus clarkii. Journal of Crustacean Biology, 10: 492-497.

Taylor, C.A. 2002. Taxonomy and Conservation of Native Crayfish Stocks. p. 236-257. In: D.M. Holdich (ed), Biology of Freshwater Crayfish. New York, WileyBlackwell.

Thune, R. 1994. Diseases of Louisiana crayfish. p. 117-156. In: J.V. Huner (ed), Freshwater Crayfish Aquaculture in North America, Europe and Australia. New York, Food Products Press.

Thune, R.; Hawke, J.P. and Siebeling, R.J. 1991.Vibriosis in the red swamp crawfish. Journal of Aquatic Animal Health, 3: 188-191.

Torres, E. and Álvarez, F. 2012. Genetic variation in native and introduced populations of the red swamp crayfish Procambarus clarkii (Girard, 1852) (Crustacea, Decapoda, Cambaridae) in Mexico and Costa Rica. Aquatic Invasions, 7(2): 235-241.

Turner, H.M. 1984. Orientation and Pathology of Allocorrigia filiformis (Trematoda: Dicrocoeliidae) from the Antennal Glands of the Crayfish Procambarus clarkii. Transactions of the American Microscopical Society, 103(4): 434-437.

Turner, H.M. 2004. Seven-month survey of Allocorrigia filiformis (Trematoda: Dicrocoeliidae) infection in the crayfish Procambarus clarkii. The Southwestern Naturalist, 49(2): 256-257.

Usio, N.; Konishi, M. and Nakano, S. 2001. Species displacement between an introduced and a 'vulnerable' crayfish: the role of aggressive interactions and shelter competition. Biological Invasions, 3: 179-185.

Velez, S. 1980. Problematica y perspectivas de la introduction del cranguejo: El cangrejo rojo de la Marisma. Jornadas de Estudio, 25-31.

Vogt, G. and Tolley, L. 2004. Brood care in freshwater crayfish and relationship with the offspring's sensory deficiencies. Journal of Morphology, 262: 566-582.

Volonterio, O. 2009. First report of the introduction of an Australian temnocephalidan into the New World. Journal of Parasitology, 95: 120-123.

Westman, K. 1991. The crayfish fishery in Finland: its past, present and future. Finnish Fisheries Research, 12: 187216.

Westman, K.; Pursiainen, M. and Vilkman, R. 1979. A new folding trap model which prevents crayfish from escaping. Freshwater Crayfish, 4: 235-242.

Westman, K.; Sumari, O. and Pursiainen, M. 1978. Electric fishing in sampling crayfish. Freshwater Crayfish, 4: 251255. 
Williams, E.H. Jr.; Bunkley-Williams, L.; Lilyestrom, C.G. and Ortiz-Corps, E.A.R. 2001. A review of recent introductions of aquatic invertebrates in Puerto Rico and implications for the management of nonindigenous species. Caribbean Journal of Science, 37: 246-251.

Wilson, A.B.; Naish, K.A. and Boulding, E.G. 1999. Multiple dispersal strategies of the invasive quagga mussel (Dreissena bugensis) as revealed by microsatellite analysis. Canadian Journal of Fisheries and Aquatic Sciences, 56: 2248-2261.

Witte, F; Goldschmidt, T.; Wanink, J.; Oijen, M.; Goudswaard, K.; Witte-Maas, E. and Bouton, N. 1992. The destruction of an endemic species flock: quantitative data on the decline of the haplochromine cichlids of Lake Victoria. Environmental Biology of Fishes, 34: 1-28.
Wizen, G.; Galil, B.S.; Shlagman, A. and Gasith, A. 2008. First record of red swamp crayfish, Procambarus clarkii (Girard, 1852) (Crustacea: Decapoda: Cambaridae) in Israel - too late to eradicate? Aquatic Invasions, 3: 181-185.

Yamamoto, Y. 2010. Contribution of bioturbation by the red swamp crayfish Procambarus clarkii to the recruitment of bloom-forming cyanobacteria from sediment. Journal of Limnology, 69: 102-111.

Yan, X.; Zhenyu, L.; Gregg, W.P. and Dianmo, L. 2001. Invasive species in China - an overview. Biodiversity and Conservation, 10: 1317-1341.

Yue, G.H.; Li, J.; Bai, Z.; Wang, C.M. and Feng, F. 2010. Genetic diversity and population structure of the invasive alien red swamp crayfish. Biological Invasions, 12: $2697-$ 2706. 